\title{
Infectious pancreatic necrosis in Atlantic salmon Salmo salar in relation to specific antibodies, smoltification, and infection with erythrocytic inclusion body syndrome (EIBS)
}

\author{
J. Jarp ${ }^{1, *}$, T. Taksdal ${ }^{1}$, B. Tørud ${ }^{2}$ \\ ${ }^{1}$ Central Veterinary Laboratory, POB 8156 Dep., N-0033 Oslo, Norway \\ ${ }^{2}$ Veterinary Service in Aquaculture, N-6683 Vågland, Norway
}

\begin{abstract}
This paper examines the association between (1) specific antibodies against infectious pancreatic necrosis virus (IPNV), (2) plasma chloride levels, (3) infection with erythrocytic inclusion body syndrome (EIBS), and the risk of clinical infectious pancreatic necrosis (IPN) and cumulative mortality in sea-cultured Atlantic salmon post-smolt. The field study initially included 29 smolt groups raised in 10 freshwater hatcheries. The groups were transferred to seawater in spring 1993 and monitored from just prior to seawater transfer until 1 October the same year. Before seawater transfer, specific antibodies against IPNV were found in $62.1 \%$ of the groups. Anti-IPNV antibodies were most frequently detected in fish which had suffered from clinical IPN during the fry period. However, only antibody-positive groups in which no earlier outbreaks of IPN had been recorded during the fresh water stage appeared to be protected against IPN outbreaks after transfer to the sea. The cumulative mortalities in seawater for groups which were positive or negative for IPNV-antibodies prior to seawater transfer were 3.9 and $6.6 \%$, respectively. No relationship was found between the hypo-osmoregulatory capacity or infection with EIBS and the risk of clinical IPN after seawater transfer. The group-level prevalence of ElBS was $48.3 \%$ before seawater transfer, decreasing to 42.1 and $28.9 \%$ for the first and second samplings after seawater transfer, respectively. The protective effect of acquired specific humoral immunity shown in the present study may be important for the control of IPN in farmed salmonids.
\end{abstract}

KEY WORDS: Epidemiology · Infectious pancreatic necrosis · Atlantic salmon - Immunity · Smoltification - EIBS

\section{INTRODUCTION}

The Norwegian sea-caged population of Atlantic salmon Salmo salar L. has suffered from major disease problems for many years. High incidence of bacterial diseases such as vibriosis, cold-water vibriosis, and furunculosis resulted in serious losses during the 1980 s and early 1990s (Jarp et al. 1995). The introduction of effective vaccines against the dominant bacterial diseases has dramatically reduced the incidence of these diseases in cultured salmonids (Lillehaug 1989). For viral diseases the situation is less favourable. For approximately 4 mo after seawater transfer of smolt in

·E-mail: jorun.jarp@vetinst.no the spring of 1991, infectious pancreatic necrosis (IPN) occurred in $39.5 \%$ of the sea sites housing post-smolt (Jarp et al. 1995). Subsequently the incidence of clinical IPN remained high (Jarp \& Rosten 1993). Since outbreaks of IPN in post-smolt are associated with mortalities, it is of major importance to clarify risk factors influencing its occurrence.

An epidemiological study of IPN in post-smolt in 1991 revealed that the risk of clinical IPN was related to the mixing of smolt from many freshwater hatcheries at the same sea site (Jarp et al. 1995). Although the prevalence of infectious pancreatic necrosis virus (IPNV) carriers in smolt before seawater transfer has not been systematically investigated, it has been shown that a large number of Norwegian salmonid 
seawater farms harbour IPNV-carriers (Melby et al. 1991). It is likely that the infection is carried with the smolt to the sea site; however, the causal mechanisms triggering outbreaks of IPN after seawater transfer are not known.

Reduced immunologic capacity during smoltification has been demonstrated in coho salmon (Maule et al. 1987), sea trout (Muona \& Soivo 1992), and Atlantic salmon (Muona \& Soivo 1992, Melingen et al. 1995). In contrast, Olsen et al. (1993) found no suppression of non-specific immunity during the smoltification period in 1-yr-old Atlantic salmon. It has been assumed that impaired smoltification of the fish before seawater release may lead to reduced disease resistance in the post-smolt period.

Following the demonstration of humoral neutralizing antibodies against IPNV after injection of the virus into adult salmonids by Wolf \& Quimby (1969), the protective effect of acquired specific immunity against outbreaks of IPN has been investigated. In a study of 2-yr-old rainbow trout, Yamamoto (1975) found that fish with high concentrations of specific antibodies were frequently IPNV-negative. However, Reno et al. (1978), Smail \& Munro (1985), and Melby \& Falk (1995) found no association between the presence of IPNV and specific antibodies in healthy rainbow trout and Atlantic salmon. Others have shown that IPNV and specific antibodies may co-exist for a long time in salmonid carriers (Ahne \& Thomsen 1986, Bootland et al. 1990).

Natural occurrence of an erythrocytic inclusion body syndrome (EIBS) was first described in Chinook salmon (Leek 1987). Since then it has been recorded in several salmonid populations (Rodger et al. 1991, Foott et al. 1992, Takahashi et al. 1992), including Norwegian farmed Atlantic salmon (Lunder et al. 1990). EIBS may be associated with anaemia in juveniles, and in some cases increased mortality has been observed (Takahashi et al. 1992). The possibility that EIBSpositive fish may be subject to an increased risk of contracting IPN has been discussed but never substantiated.

The purpose of this study was to determine if there is any association between. (1) the presence of specific antibodies against IPNV, (2) the smoltification status of Atlantic salmon smolt, (3) the prevalence of EIBS, and the risk of clinical IPN and cumulative mortality of post-smolt in seawater.

\section{MATERIALS AND METHODS}

Design. The study was designed as a prospective longitudinal study with smolt groups as the observation unit. The fish in a defined smolt group had an identical genetic background and vaccination status and were kept in the same freshwater tank from the time of the last vaccination until seawater transfer A total of 29 smolt groups destined for seawater transfer between 25 April to 1 August 1993 were included in the study. During the study period samples from each group were collected 3 times: just before seawater transfer, and about 2 and 6 wk after transfer. On each occasion the specific antibody response against IPNV was tested, hypo-osmoregulatory capacity was measured, and potential EIBS-infection investigated. Prior to seawater transfer pancreas tissue was examined for histological alterations.

At the start of the study, site and fish data at the freshwater hatchery were recorded retrospectively by the local veterinarian using a 2-page questionnaire. At the sea site a questionnaire was used to directly register on-farm data. The study groups were observed for the occurrence of specific diseases and total cumulative mortality until 1 October of the same year.

Enzyme-linked immunosorbent assay (ELISA). For detection of anti-IPNV antibodies in plasma, an indirect enzyme-linked immunosorbent assay (ELISA) as described by Håvardstein et al. (1990) and later adjusted by Melby \& Falk (1995) was performed with some modifications.

IPNV Sp serotype, grown in CHSE-214 cells (Lannan et al. 1984) and uninfected CHSE-214 cells were used as antigen preparations as described by Melby \& Falk (1995). Microtitre plates (96 wells, Nunc-Immuno Plate MaxiSorp ${ }^{T N}$ ) were coated with $100 \mu$ lantigen solution ( $3 \mu \mathrm{g}$ protein $\mathrm{ml}^{-1}$ ) per well. IPNV-antigen was added to 48 wells, and uninfected cell culture-antigen to the remaining 48 wells. The plates were incubated at $4^{\circ} \mathrm{C}$ for a minimum of 1 night and a maximum of $6 \mathrm{~d}$ before the antigen solution was discarded. To block nonspecific protein binding, the wells were incubated with $190 \mu \mathrm{l}$ of either $5 \%$ non-fat dry milk in phosphatebuffered saline (PBS) with $0.2 \%$ Tween 20 , or $1 \%$ bovine serum albumin (BSA) in PBS, both at $\mathrm{pH} 7.4$ for $60 \mathrm{~min}$ at $37^{\circ} \mathrm{C}$. Then $100 \mu \mathrm{l}$ plasma samples, diluted $1: 100,1: 200$ and $1: 400$ in blocking solution, were added to each well before incubation at $4^{\circ} \mathrm{C}$ overnight. All dilutions were added both to wells coated with IPNV-antigen and to wells coated with cell cultureantigen. Subsequently, $100 \mu \mathrm{l}$ of monoclonal antibody against Atlantic salmon immunoglobulin (D5 or C7. kindly provided by Dr Hans Jørgen Larsen, Norwegian College of Veterinary Medicine, Oslo, Norway), diluted 1:15000 in PBS, pH 7.4, were added to each well. The plates were then sealed and left to react for $1 \mathrm{~h}$ at room temperature. After addition of $100 \mu \mathrm{l}$ of peroxidaseconjugated sheep anti mouse IgG (Amersham NA 931), diluted $1: 2000,1: 1000$ or 1:500 in PBS, pH 7.4 to each well, the plates were incubated for $1 \mathrm{~h}$ at room temper- 
ature. Then $100 \mu \mathrm{l}$ of substrate (o-phenylenediamine dihydrochloride, Sigma Immuno Chemicals ${ }^{\text {(1) }}$ P-3804) were added to each well to visualise the bound enzyme. The colour reaction was stopped after $20 \mathrm{~min}$ at room temperature by addition of $100 \mu$ of $1 \mathrm{M} \mathrm{H}_{2} \mathrm{SO}_{4}$ The colour intensity was read by an automatic ELISAreader at $492 \mathrm{~nm}\left(\mathrm{~A}_{492}\right)$. Positive and negative plasma samples, identical to those described by Melby \& Falk (1995), were included on each microtitre plate.

The results were considered positive with regard to antibody response against IPNV when at least 2 of the 3 serum dilutions gave a minimum $\mathrm{A}_{492}$ difference of 0.2 between colour reactions of wells coated with IPNV and wells coated only with uninfected cell culture antigen. All samples were examined twice. Any sample showing variable results was re-examined and considered positive only if 2 of 3 parallel tests gave positive results.

Seawater challenge test and plasma chloride analyses. Prior to seawater transfer, 25 fish from each smolt group were collected and transported in plastic bags containing water and oxygen from the freshwater hatchery to a test station. The fish were kept in tanks with fresh water for $1 \mathrm{~d}$ and then transferred to tanks with constantly aerated $35 \%$ seawater Raw seawater was filled into the tanks and adjusted to 35\% with hw-Marinemix, Wimex ${ }^{(W}$ (Wiegandt, GMBH, Krefeld, Germany). No feed was offered to the fish during testing. The experimental exposure to seawater lasted for $24 \mathrm{~h}$, and the fish were weighed and blood samples withdrawn from the caudal vein into heparinized evacuated blood collecting tubes. Plasma samples were collected from 10 fish in each group, 2 and 6 wk after seawater transfer.

The samples were kept on ice while blood smears were made, and then centrifuged at $1741 \times g$ for $5 \mathrm{~min}$, the plasma extracted and immediately frozen at $-18^{\circ} \mathrm{C}$ After transfer to the laboratory, the plasma samples were maintained at $-70^{\circ} \mathrm{C}$.

The plasma chloride values were analyzed using a Radiometer CMT 10 Chloride Titrator. All samples were analyzed twice, and the paired mean values were used for further analyses. The chloride values prior to seawater transfer were excluded in 1 group due to an accident with the water supply during seawater challenge.

Erythrocytic inclusion body syndrome (EIBS). At each sampling, blood smears from 5 fish per group were prepared, air dried, and fixed in methanol for 5 min. After staining with Leishman-Giemsa, the smears were examined by light microscopy at $1000 x$ magnification. At least 60 microscopic fields were examined before a fish was classified as negative. If EIBS-like inclusions were detected in a field of view, an additional 20 fields were examined to confirm a positive diagnosis of EIBS. A smolt group was classified as EIBS-positive if inclusions were diagnosed in the red blood cells of 1 of the 5 fish sampled.

Pathology. During disease outbreaks, samples of pyloric caeca with attached pancreatic tissue from moribund fish were fixed in $10 \%$ phosphate-buffered formalin. The tissue samples were processed and embedded in paraffin wax using standard procedures. Sections ( 4 to $6 \mu \mathrm{m}$ ) were stained with haematoxylin and eosin (H\&E) and examined by light microscopy Samples with pancreatic lesions were examined immunohistochemically for the identification of IPNV (Evensen \& Rimstad 1990, Taksdal et al. 1995). A positive diagnosis of IPN was based on exocrine pancreatic necrosis together with positive reactivity for IPNV in the pancreatic lesions.

Before the study started, all smolt groups had been under regular health surveillance by the local fish health veterinarian. Routine diagnostic procedures included sampling of pancreatic tissues if IPN could be suspected. Smolt groups which had experienced a clinical IPN outbreak prior to the start of the study were classified as historic IPN The same routine diagnostic procedures were also carried out by the local fish health service during the study period.

In order to diagnose possible subclinical cases of IPN before seawater transfer, samples of pancreatic tissue from 5 salmon smolts per group were collected immediately after blood sampling and examined as described above.

Statistical analyses. The statistical analyses were performed in the SAS-PC System ${ }^{\oplus}$ Version 6.08 for Windows (SAS Institute Inc., Cary, NC, USA, 1989) and EGRET (Statistics and Epidemiology Research Corporation, Seattle, USA, 1991), using smolt group as the statistical unit. The prevalence of specific antibodies against IPNV and infection with EIBS is given by the group-level prevalence representing the mean value within the group and the prevalence representing the prevalence when groups are classified as negative or positive. The arithmetic mean of the individual chloride values in the sample was used as the group mean value.

Student's $t$-test was used to test for a difference in mean values of continuously distributed variables between classes. The strenght of the association between an exposure factor and disease is estimated by the relative risk (RR) where the cumulative risk in the exposed goup is related to the cumulative risk in a baseline reference unexposed group. The exact $95 \%$ confidence intervals (CI) were calculated, but due to the presence of zero in some cells of the frequencies tables in the stratified analysis, 0.5 was added to each cell when stratified RR and confidence limits were calculated. 


\section{RESULTS}

\section{Descriptive results}

Of the 29 included groups 22 consisted of 1 -yr-old smolt with a mean body weight of $46.2 \mathrm{~g}$ before seawater transfer, while the average weight of the fish in seven 2 -yr-old smolt groups was $168.0 \mathrm{~g}$.

After sea-water transfer, fish from 8 of the initial 29 groups were distributed among various sea sites, whereas 1 group dropped out of the study. At this stage the material comprised 38 post-smolt groups kept in 24 sea sites. From 1 group no blood samples were collected in the second sampling.

The earliest and latest tests of the hypo-osmoregulatory ability of the fish prior to sea-water transfer were performed on 26 April and 12 July, respectively. On average, the fish were transferred to sea $4.1 \mathrm{~d}$ after the seawater challenge. A total of 19.2 d elapsed before the second sampling and an additional $28.9 \mathrm{~d}$ until the third sampling. The mean length of the period from sea-water transfer to the second and third sampling was 15.0 and $44.0 \mathrm{~d}$, respectively.

\section{Pathological examinations}

No pathological changes typical of IPN were detected prior to seawater transfer in 28 of the 29 groups. In the remaining group, 1 of 5 tissue sections tested

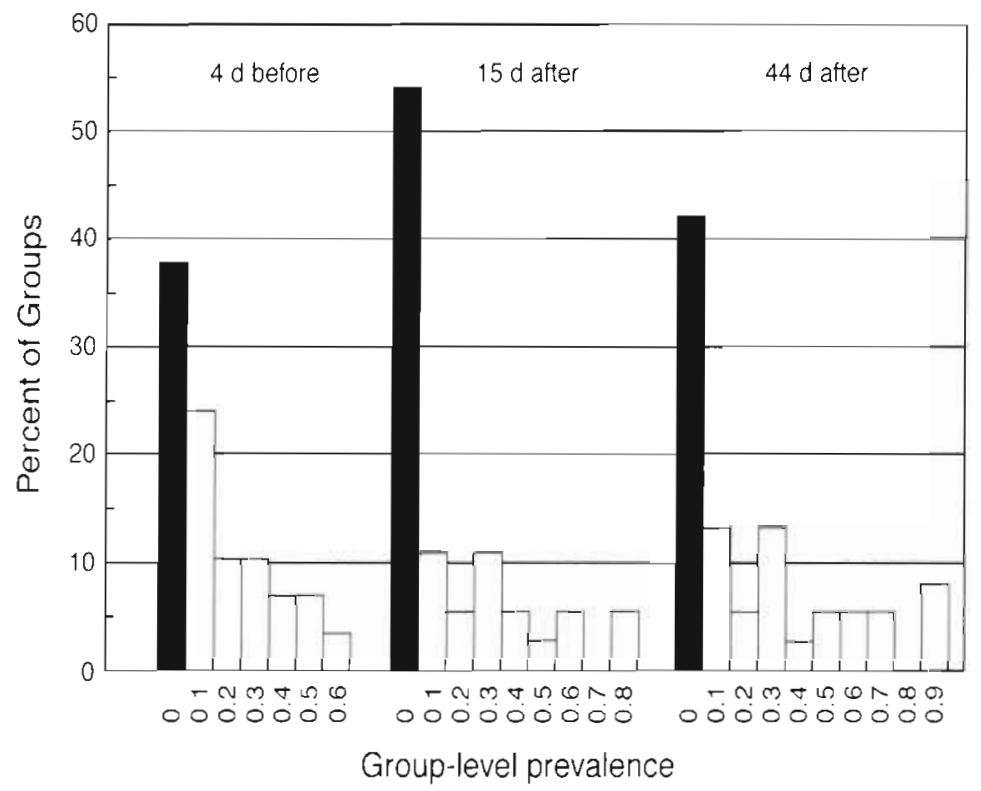

Fig. 1 Distribution of group-level prevalence of specific antibodies against IPNV in plasma in relation to the 3 sequential samplings performed in 29 smolt groups on average $4 \mathrm{~d}$ prior to seawater transfer and in 38 post-smolt groups on average 15 and $44 \mathrm{~d}$ after seawater transfer had multifocal, though non-extensive, necrosis of exocrine pancreatic tissue. Immunohistochemical examination revealed IPNV-antigen in these lesions, indicating subclinical IPN. No historic IPN had been reported during the freshwater period, and no clinical IPN was observed during the study period. Historic IPN had been recorded previously in 8 other groups. During the observation period in seawater, outbreaks of IPN were diagnosed in 8 of the 38 post-smolt groups.

\section{Specific antibodies to IPNV}

Prior to seawater transfer, specific antibodies against IPNV were detected in 18 (62.1\%) of the 29 groups, a maximum group-level prevalence of $60 \%$ was found (Fig. 1), At the first and second sampling after seawater transfer, antibodies were found in 45.9 and $57.9 \%$ of the groups, respectively. In $15(40.5 \%)$ of the 37 groups, no specific antibodies were found at any sampling.

Prior to seawater transfer, the mean group-level prevalence of specific antibodies against IPNV in 1-yr-old (0.16) and 2-yr-old smolt (0.15) was quite similar. In groups which had suffered from clinical IPN during the freshwater period, the mean grouplevel prevalence of specific antibodies against IPNV was estimated to be $27 \%$ prior to sea-water transfer, whereas in the corresponding IPN-negative groups the prevalence was $12 \%$ (Table 1 ).

The mean freshwater temperature recorded during the month prior to the first sampling was $8.5^{\circ} \mathrm{C}$ in groups demonstrated to be IPNV-antibody positive prior to release in the sea site. This was higher than the average of $5.6^{\circ} \mathrm{C}$ in the parallel negative groups $(p<0.06)$.

For fish which had acquired specific immunity against IPNV prior to transfer to the sea site, the unadjusted RR of clinical IPN in the post-smolt period was 0.6 (95\% CI: 0.2 to 2.2) compared with antibody-negative groups as the reference level (Fisher exact $p$-value: 0.35). Based on historic IPN during the freshwater period, a stratified analysis of the risk of IPN in relation to antibody-status was performed, because it appeared that the risk was not homogeneous across the strata as can be seen by the incidence rate of clinical. IPN per 100 group-days at risk after seawater transfer in Table 2. IPN was not diagnosed in the seawater period in any of the 12 antibodypositive groups with no previous history of clinical IPN, leading to an RR of $0.15(95 \%$ CI: 0.0 to 2.6 ) when compared to the antibody- 
Table 1. Mean group-level prevalence of EIBS and specific antibodies against IPNV in the smolt and post-smolt stage in relation to age of fish and occurrence of clinical IPN in freshwater and seawater sites. Mean date of sampling given in days prior to or after transfer to seawater

\begin{tabular}{|c|c|c|c|c|c|c|c|}
\hline \multirow[t]{2}{*}{ Variable } & \multirow{2}{*}{$\begin{array}{l}\text { Groups } \\
(\mathrm{N})\end{array}$} & \multicolumn{3}{|c|}{ Prevalence of EIBS-infection } & \multicolumn{3}{|c|}{ Prevalence of specific antibodies against IPNV } \\
\hline & & $4 \mathrm{~d}$ before & $15 \mathrm{~d}$ after & $44 \mathrm{~d}$ after & $4 \mathrm{~d}$ before & $15 \mathrm{~d}$ after & $44 \mathrm{~d}$ after \\
\hline \multicolumn{8}{|c|}{ Age of smolt } \\
\hline 1 -yr-old & 22 & $0.20^{\circ}$ & 0.23 & 0.13 & 0.16 & 0.18 & 0.24 \\
\hline $2-y r-o l d$ & 7 & $0.54^{\circ}$ & 0.24 & 0.20 & 0.15 & 0.09 & 0.18 \\
\hline \multicolumn{8}{|c|}{ Historic IPN recorded in fresh water } \\
\hline No & 21 & 0.28 & $0.10^{\circ}$ & 0.13 & 0.12 & $0.10^{\circ}$ & $0.13 \cdots$ \\
\hline Yes & 7 & 0.29 & $0.53^{\circ}$ & 0.23 & 0.27 & $0.44^{\circ}$ & $0.63 \cdots$ \\
\hline \multicolumn{8}{|c|}{ Clinical IPN observed in seawater } \\
\hline $\mathrm{N}_{0}$ & 30 & 0.34 & 0.25 & 0.15 & 0.12 & 0.13 & 0.21 \\
\hline Yes & 8 & 0.21 & 0.28 & 0.18 & 0.15 & 0.28 & 0.35 \\
\hline
\end{tabular}

negative groups. In contrast, in 3 of 7 antibody-positive groups with historic IPN, clinical IPN reoccurred during the observation period in seawater, leading to an estimate of RR of 1.8 (95\% CI: 0.1 to 21.9) for antibodypositive smolt compared to antibody-negative smolt.

In groups in which specific antibodies against IPNV were detected prior to seawater release the total cumulative mortality during the observation period in the sea was $3.9 \%$, the corresponding figure for the antibody-negative groups being $6.6 \%(p<0.06)$.

\section{Plasma chloride concentration}

Prior to seawater transfer but after experimental challenge with seawater for $24 \mathrm{~h}$, the average plasma chloride level for all groups was $153.0 \mathrm{mM}$, the corresponding value for the first and second sampling after seawater transfer being 142.0 and $143.3 \mathrm{mM}$, respectively. Prior to seawater transfer, the average chloride concentration was $152.4 \mathrm{mM}$ in 1 -yr-old smolt and $152.8 \mathrm{mM}$ in 2-yr-old smolt. However, the plasma chloride concentrations for 1-yr-old smolt decreased from $157.0 \mathrm{mM}$ when tested in April-May to $150.1 \mathrm{mM}$ in June-July. All 2-yr-old smolt were transferred to seawater during April-May.

Smolt groups with historic IPN during the freshwater period had slightly higher plasma chloride concentrations (156.9 $\mathrm{mM})$ than smolt with no history of IPN $(152.4 \mathrm{mM})(\mathrm{p}=0.29)$. However, after seawater transfer the chloride concentrations in the historic IPN-positive groups were lower than the corresponding IPNnegative groups (Table 3 ). No relationship between the hypo-osmoregulatory ability and the risk of IPN after seawater transfer could be demonstrated, as the mean plasma chloride levels for fish which developed clinical IPN were quite similar for all 3 samplings (Table 3).

Table 2. Incidence rate per 100 group-days at risk after seawater transfer and the adjusted cumulative relative risk of clinical IPN after seawater transfer in relation to whether IPN had been recorded in the freshwater stage and to the status of specific IPNV antibodies prior to seawater transfer

\begin{tabular}{|c|c|c|c|c|}
\hline & \multicolumn{2}{|c|}{ Historic IPN in freshwater period } & \multicolumn{2}{|c|}{ No historic IPN in freshwater period } \\
\hline & $\begin{array}{l}\text { Specific IPNV-antibodies } \\
\text { prior to seawater transfer }\end{array}$ & $\begin{array}{l}\text { No specific IPNV-antibodies } \\
\text { prior to seawater transfer }\end{array}$ & $\begin{array}{l}\text { Specific IPNV-antibodies } \\
\text { prior to seawater transfer }\end{array}$ & $\begin{array}{l}\text { No specific IPNV-antibodies } \\
\text { prior to seawater transfer }\end{array}$ \\
\hline No. of cases & 3 & 0 & 0 & 4 \\
\hline No. of noncase & ses & 1 & 12 & 13 \\
\hline $\begin{array}{l}\text { Total no. of da } \\
\text { at risk for all g }\end{array}$ & $\begin{array}{l}\text { ays } \\
\text { groups }\end{array}$ & 134 & 1403 & 1830 \\
\hline $\begin{array}{l}\text { Incidence rate } \\
100 \text { group-day }\end{array}$ & $\begin{array}{l}\text { e per } \quad 0.44 \\
\text { ys at risk }\end{array}$ & 0 & 0 & 0.22 \\
\hline Relative risk & $1.8(0.1-21.9)^{\mathrm{a}}$ & $1^{\mathrm{b}}$ & $0.15(0.01-2.6)^{\mathrm{a}}$ & $1^{b}$ \\
\hline
\end{tabular}


Table 3. Mean values of plasma chloride ( $\mathrm{mM}$ ) ( $95 \%$ confidence intervals) in the fish groups in the smolt and post-smolt stage in relation to records of clinical IPN in the freshwater hatchery and observed clinical IPN in the seawater site. Mean date of sampling given in days prior to or after transfer to seawater

\begin{tabular}{|c|c|c|c|c|}
\hline \multirow[t]{2}{*}{ Variable } & \multirow{2}{*}{$\begin{array}{c}\text { Groups } \\
\text { (N) }\end{array}$} & \multicolumn{3}{|c|}{ Mean plasma chloride values (mM) } \\
\hline & & $4 \mathrm{~d}$ before & $15 \mathrm{~d}$ after & $44 \mathrm{~d}$ after \\
\hline \multicolumn{5}{|c|}{ Historic IPN recorded in fresh water } \\
\hline No & 21 & $152.4(148.0-156.7)$ & $142.9(140.3-145.4)$ & $143.4(139.2-147.5)$ \\
\hline Yes & 7 & $156.9(150.0-163.9)$ & $138.3(1.29 .8-146.8)$ & $141.1(137.3-144.9)$ \\
\hline \multicolumn{5}{|c|}{ Clinical IPN observed in seawater } \\
\hline No & 30 & $154.6(152.6-158.7)$ & $142.3(139.5-145.0\}$ & $143.3(139.1-147.5)$ \\
\hline Yes & 8 & $152.7(151.1-154.4)$ & $141.0(133.6-148.4\}$ & $141.4(137.9-144.9)$ \\
\hline
\end{tabular}

\section{EIBS}

The number of EIBS-positive groups declined from $48.3 \%$ before seawater release to $42.1 \%$ for the first sampling and $28.9 \%$ for the second sampling after seawater transfer (Fig. 2). Of the 37 groups investigated for EIBS in all 3 samplings $14(37.8 \%)$ were negative for EIBS on each occasion, whereas 5 of the 19 groups which were EIBS-negative prior to seawater transfer subsequently became positive.

Before seawater transfer, the prevalence of EIBS in 2 -yr-old smolt (0.54) was significantly higher than the prevalence in 1 -yr-old smolt $(0.20)(p<0.05)$ (Table 1$)$. The prevalence of EIBS in fish with historic IPN during the freshwater period was 0.29 , whereas in IPN-free groups the mean positive proportion was 0.28 . The odds ratio of clinical IPN for the EIBS-positive groups compared to the EIBS-negative groups prior to seawater transfer was calculated to be 0.9 (95\% CI: 0.6 to 1.2). During the observation period in seawater, the total cumulative mortality in groups classified as
EIBS-positive prior to seawater transfer was $5.0 \%$, compared to $4.9 \%$ for the corresponding EIBS-negative groups.

\section{DISCUSSION}

Smolt with no historic IPN recorded during the freshwater period but which had acquired specific humoral immunity against IPNV prior to seawater transfer were protected against clinical IPN during a time period of approximately 4 mo after seawater transfer. Such specific protective immunity against new infections with a homologous agent has been demonstrated experimentally for several virus infections. It has been shown that coho salmon artificially infected with EIBS which recovered from the disease were less susceptible to rechallenge with EIBS (Piacentini et al, 1989). Houghton (1994) demonstrated protection against re-infection with tissue homogenates infected with the etiologic agent of pancreas disease in both Atlantic salmon parr and post-smolts. Recently, it has also been demonstrated that Atlantic salmon artificially infected with infectious salmon anaemia (ISA) were less sensitive to new infection (Falk \& Dannevig 1995). The observed protective effect of the humoral immune response against clinical IPN gained under natural conditions may be very important when considering vaccination as a measure in a strategy to control. IPN.

Outbreaks of IPN during the freshwater stage increased the likelihood of detection of a specific antibody response against IPNV. Nevertheless, these groups were at a higher risk of reoccurrence of IPN after seawater transfer when compared to the fish without specific antibodies in the same strata. Prior to seawater transfer no pathological changes in the pancreatic tissue could be demonstrated in the fish with historic IPN, but their general
Fig. 2. Distribution of group-level prevalence of EIBS-infection in rela tion to the 3 sequential samplings performed in 29 smolt groups on average $4 \mathrm{~d}$ prior to seawater transfer and in 38 post-smolt groups on average 15 and 44 d after seawater transfer 
condition might have been disturbed due to the outbreak of the disease. In animals infected with various Herpes viruses, reactivation of virus may occur even when antibodies are produced by the host (Mellerick \& Fraser 1987). Such reactivation may follow a stimulation of the cells harbouring the virus (Klein 1985). Bootland et al. (1990) found that if fry were immunized with inactivated IPNV vaccine, protection was only achieved in specific age groups of fish. Further studies should be performed in order to confirm the results from this small study and to determine whether the time of infection with IPNV might influence on the development of specific immunity against IPNV and protection against subsequent clinical IPN

Specific antibodies against IPNV were detected in more than $60 \%$ of the fish groups prior to seawater transfer. As the prevalence of IPNV carriers has been reported to be very high in the Norwegian farmed population (Melby et al. 1991), it is not surprising to find indications of frequent exposure to IPNV. Clinical IPN had only been recorded in some of the groups. The production of antibodies against IPNV in the other groups may be due to a prior or continuing subclinical natural infection or a non-recorded clinical IPN with unspecific mortality. In another experimental study including 20-mo-old smolt prior to seawater transfer, specific antibodies against IPNV were detected in $36 \%$ of the fish examined and a prevalence of IPNV of $41 \%$. However, no association was found between the presence of virus and specific antibodies (Melby \& Falk 1995).

The examination of all plasma samples for antibodies against IPNV included wells where IPNV antigen was omitted from the antigen coat of the microtitreplate. Melby \& Falk (1995) have shown that some plasma samples give significant reactions against this control cell culture antigen. In the present study, a notable proportion of the plasma samples showed this nonspecific background reaction, increasing in number and strength from the first to the last sampling. A similar finding was reported by Olesen et al. (1991) using an indirect antigen capture ELISA for the detection of antibodies to Egtved virus in trout. They obtained both better sensitivity and specificity with the ELISA when the differences between the reactivity in wells coated with virus antigen and in wells where the virus antigen layer was omitted were taken into account. The cause of this unspecific reactivity is unknown, but could be due to polyspecific natural or crossreacting antibodies (Gonzalez et al. 1988, Michel et al. 1990). The sensitivity and specificity of the ELISA in the present study is not known. As most fish farms in Norway probably harbour IPNV carriers, and since use of cell culture for isolation of IPNV is not an accurate procedure for detection of IPNV, unquestionably negative plasma samples cannot be obtained. In our opinion, the use of a negative antigen control in the ELISA should solve this problem.

No relationship was found between EIBS and the risk of clinical IPN in post-smolts, and no increased mortality was observed in EIBS-infected post-smolt during the first months after seawater transfer. In fish artificially infected with EIBS, increased mortalities were observed when compared to negative controls (Tanaka et al. 1994). The fish in the present study were healthy prior to seawater transfer, and the level of EIBS-infection might have been less severe than in artificially infected fish. The prevalence of EIBS prior to seawater release was significantly higher in 2-yr-old smolt than in yearling fish, which can be explained by a longer exposure period to EIBS through fresh water.

The validity of the present small field study may be questioned, as the study groups were sampled by convenience. However, the studied freshwater and seawater farms are commercial farms representative of the area. In the statistical analyses no adjustment was made for potential cluster effect within the freshwater or sea site when several groups from the same site were included. Exact methods were used to test homogeneity across class levels and in the estimation of confidence intervals. However, the trends in the achieved results are uniform and biologically plausible, and hopefully contribute to a better understanding of the mechanism of IPN in post-smolts

Acknowledgements. This study was funded by the Norwe. gian Research Council and the Norwegian Ministry of Agriculture. The technical skills of Per Lorentzen, Marit Ren, and Marianne Heum are very much appreciated, and the authors also thank the fish-farmers who contributed to the study.

\section{LITERATURE CITED}

Ahne W. Thomsen I (1986) Infectious pancreatic necrosis detection of virus and antibodies in rainbow trout IPNVcarrier (Salmo gairdneri). J Vet Med Ser B 33:552-554

Bootland LM, Dobos P, Stevenson RMW (1990) Fry age and size effect on immersion immunization of brook trout, Salvelinus fontunalis Mitchell, against infectious pancreatic necrosis virus. J Fish Dis 13:113-125

Evensen $\varnothing$. Rimstad E (1990) Immunohistochemical identification of infectious pancreatic necrosis virus in paraffinembedded tissues of Atlantic salmon (Salmo salar). J Vet Diagn Invest 2:288-293

Falk K, Dannevig BH (1995) Demonstration of a protective immune response in infectious salmon anaemia (ISA). infected Atlantic salmon Salmo salar. Dis Aquat Org 21 $1-5$

Foott JS, Miller A, Steiner R, Hedrick RP. (1992) Erythrocytic inclusion body syndrome (EIBS) infection of chinook salmon in Idaho. J Aquatic Anim Health 4:306-308

Gonzalez R, Charlemagne J, Mahana W, Avrameas S (1988) Specificity of natural serum antibodies present in phylo- 
genetically distinct fish species. Immunology 63:31-36

Houghton G (1994). Acquired protection in Atlantic salmon Salmo salar parr and post-smolts against pancreas disease. Dis Aquat Org 18:109-118

Hàvardstein LS, Endresen C. Hjeltnes B, Christie KE, Glette J (1990) Specific immunoglobulins in serum from Atlantic salmon Salmo salar L., immunized with Vibrio salmonicida and infectious pancreatic necrosis virus. J Fish Dis 13: $101-111$

Jarp J, Gjevre AG, Olsen AB, Bruheim T (1995) Risk factors associated with furunculosis, infectious pancreatic necrosis, and mortality in post-smolt of Atlantic salmon, Salmo salar L. J Fish Dis 18:67-78

Jarp J, Rosten T (1993) Bland ikkje smolt frå fleire anlegg. Norsk Fiskeoppdrett 5:41-41. (in Norwegian)

Klein RJ (1985) Initiation and maintenance of latent herpes simplex virus infections: the paradox of perpetual immobility and continous movement. Rev Infect Dis 7:21-30

Lannan CN, Winton JR, Fryer JL (1984) Fish cell lines: establishment and characterization of nine cell lines from salmonids. In Vitro 20:671-675

Leek SL (1987) Viral erythrocytic inclusion body syndrome (EIBS) occurring in juvenile spring chinook salmon (Oncorhynchus tshawytscha) reared in freshwater. Can J Fish Aquat Sci 44:685-688

Lillehaug A. (1989) A survey of different procedures used for vaccinating salmonids against vibriosis in Norwegian fishfarming. Aquaculture 83:217-226

Lunder T, Thorud K, Poppe TT, Holt RA, Rohovec JS (1990) Particles similar to the virus of erythrocytic inclusion body syndrome, ElBS, detected in Atlantic salmon (Salmo salar) in Norway. Bull Eur Ass Fish Pathol 10:21-23

Maule AG, Schreck CB, Kaattari SL (1987) Changes in the immune system of Coho salmon (Oncorhynchus kisutch) during parr-to-smolt transformation and after implantation of cortisol. Can J Fish Aquat Sci 44:161-166

Melby HP, Falk K (1995) Study of the interaction between a persistent infectious pancreatic necrosis virus (IPNV) infection and experimental infectious salmon anaemia (ISA) in Atlantic salmon, Salmo salar L. J Fish Dis 18: $579-586$

Melby HP, Krogsrud J, Håstein T, Stenwig H (1991) All commercial Atlantic Salmon seawater farms in Norway harbour carriers of Infectious Pancreatic Necrosis Virus (IPNV). In: Fryer JL (ed) Proceedings 2nd international symposium on viruses of lower vertebrates. Oregon State University, Corvallis, OR, USA, p 211-217

Melingen GO, Stefansson SO, Berg A. Wergeland HI (1995) Changes in serum protein and IGM concentration during smolting and early post-smolt period in vaccinated and unvaccinated Atlantic salmon (Salmo salar L.). Fish \& Shelffish Immunol 5:211-221

Responsible Subject Editor: F. M. Hetrick, College Park, Maryland, USA.
Mellerick DM, Fraser NW (1987) Physical state of the latent herpes simplex virus genome in a mouse model system: evidence suggesting an episomal state. Virology 158: $265-275$

Michel C, Gonzalez R, Bonjour E, Avrameas S (1990) A concurrent increase of natural antibodies and enhancement of resistance to furunculosis in rainbow trout. Ann Rech Vet 21:211-218

Muona M, Soivo A (1992) Changes in plasma lysozyme and blood leucocyte levels of hatchery-reared Atlantic salmon (Salmo salar L.) and sea trout (Salmo trutta L.) during parr-smolt transformation. Aquaculture 106:75-87

Olesen NJ, Lorenzen N, Jorgensen PEV (1991) Detection of rainbow trout antibody to Egtved virus by enzyme-linked immunosorbent assay (ELISA), immunofluoresence (IF), and the plaque neutralization tests (50\% PNT). Dis Aquat Org 10:31-38

Olsen YA, Reitan LJ, Roed KH (1993) Gill Na+, K+-ATPase activity, plasma cortisol level, and non-specific immune response in Atlantic salmon (Salmo salar) during parrsmolt transformation. J Fish Biol 43:559-573

Piacentini SC, Rohovec JC, Fryer JL (1989) Epizootiology of erythrocytic inclusion body syndrome. J Aquat Anim Health 1:173-179

Reno PW, Darley S, Savan M (1978) Infectious pancreatic necrosis: experimental induction of a carrier state in trout. J Fish Res Bd Can 35:1451-1456

Rodger HD, Drinan EM, Murphy TM, Lunder T (1991) Observations on erythrocytic inclusion body syndrome in Ireland. Bull Eur Ass Fish Pathol 11:108-111

Smail ALS, Munro DA (1985) Infectious pancreatic necrosis virus persistence in farmed Atlantic salmon (Salmo salar). In: Ellis AE (ed) Fish and shellfish pathology. Academic Press, London, p 277-288

Takahashi K, Okamoto N, Kumagai A, Maita M, Ikeda Y, Rohovec JS (1992) Epizootics of an erythrocytic inclusion body syndrome in Coho salmon cultured in seawater in Japan. J Aquat Animal Health 4:174-181.

Taksdal T, Poppe $T$, Sivertsen T, Ferguson HW (1995) Low levels of vitamin $E$ in plasma from Atlantic salmon Salmo salar with acute infectious pancreatic necrosis (IPN). Dis Aquat Org 22:33-37

Tanaka M, Okamoto N, Suzuki M, Igarashi Y, Takahashi K, Rohovec JS (1994) Experimental treatment with increased temperature of juvenile Coho salmon with EIBS. Fish Pathol 29:91-94

Wolf K, Quimby MC (1969) Infectious pancreatic necrosis: clinical and immune response in adult trouts to inoculation with live virus. J Fish Res Bd Can 26:2511-2516

Yamamoto $T$ (1975) Infectious pancreatic necrosis (IPN) virus carriers and antibody production in a population of rainbow trout (SaImo gairdneri). Can J Microbiol 21:1343-1347

Manuscript first received: January 17, 1996

Revised version accepted: July 18, 1996 